\title{
O hino "aleluiático" de Ap 19,1-7 e a celebração da Liturgia das Horas
}

\author{
The "halleluiatic" hymn of Rev 19:1-7 \\ and the celebration of the Liturgy of the Hours
}

Luiz Fernando Ribeiro Santana

\section{Resumo}

A finalidade de nossa pesquisa é mostrar o caráter litúrgico-celebrativo do hino "aleluiático de Ap 19,1-7, importante peça da celebração das II Vésperas da Liturgia das Horas dos domingos do ano litúrgico, com exceção dos domingos do Tempo da Quaresma. A reforma litúrgica pós-conciliar, ao introduzir esse Hino no contexto apenas citado, intencionou destacar a capital importância de três realidades bíblico-litúrgicas que dão sentido à celebração da Liturgia das Horas, a saber: o Dia do Senhor, a experiência de fé que a assembleia dominical é chamada a fazer com o Ressuscitado e a Liturgia das Horas como uma celebração doxológico-nupcial.

Palavras-chave: Liturgia das Horas. Domingo. Apocalipse. Celebração. Aleluia.

\section{Abstract}

The purpose of our research is to show the liturgical-celebratory character of the "halleluiatic hymn" of Rev. 19,1-7, an important part of the celebration of the Second Vespers of the Liturgy of the Hours on Sundays of the liturgical year, except for the Sundays of the Time of Lenten. The postconciliar liturgical reform, introducing this hymn in the just quoted context, intended to highlight the capital importance of three biblical-liturgical realities 
that give meaning to the celebration of the Liturgy of the Hours, namely: the Lord's Day, the experience of faith that the Sunday assembly is called to make together with the Ressurrect and the Liturgy of the Hours as a doxologicalnuptial celebration.

Keywords: Liturgy of the Hours. Sunday. Revelation. Celebration. Hallelujah.

\section{Introdução}

A reforma litúrgica pós-conciliar fez a precisa escolha de introduzir a perícope de Ap 19,1-7 na celebração das II Vésperas dos domingos do ano litúrgico, exceção feita aos domingos do Tempo da Quaresma. A nossa pesquisa tem por escopo considerar algumas razões, sobretudo de ordem teológicolitúrgica, do por que de tal escolha, certamente intencional e motivada.

Por quais motivos o hino de Ap 19,1-7 foi escolhido como parte essencial da celebração das II Vésperas da Liturgia das Horas na quase totalidade dos domingos do ano litúrgico? Que teologia encerra o "Dia do Senhor" para legitimar tal opção? Que elementos de teologia bíblica desse hino do Apocalipse poderiam fundamentar a sua inclusão na celebração da Liturgia das Horas? E, ao mesmo tempo, quais os aspectos teológicos da Liturgia das Horas que justificariam a presença desse hino como parte integrante de sua celebração?

A teologia bíblica de Ap 19,1-7, objeto da proposta desse nosso estudo, é como que a matéria-prima para abordagem que intentamos propor. De fato, é dessa perícope bíblica que podemos extrair os elementos teológicos fundamentais para compreender não apenas a sua inclusão na oração da Liturgia das Horas, como ainda para melhor percebermos o coração pulsante dessa oração litúrgica. Ao mesmo tempo, podemos e devemos afirmar que a celebração da Liturgia das Horas, na sua qualidade de ato litúrgico, torna-se o contexto vital para se compreender, em sua natureza mais profunda, o nosso hino "aleluiático".

Doravante teremos diante dos olhos os dois gonzos que nortearão a nossa reflexão: a teologia bíblica de Ap 19,1-7, por um lado, e alguns elementos essenciais que qualificam a Liturgia das Horas como ato litúrgico - a oração de Cristo prolongada em seu Corpo, a Igreja -, por outro. É à luz desses dois eixos que consideraremos três aspectos que nos parecem essenciais para a nossa proposta: o tema do Dia do Senhor, a experiência que a Igreja é chamada a fazer com o Ressuscitado na assembleia dominical e a dimensão da Liturgia 
das Horas como uma celebração doxológico-nupcial. Os dois gonzos e os três aspectos parecem-nos construir e sustentar a arquitetura da "porta" - o próprio Cristo - que, uma vez aberta, será capaz de nos colocar em contato com a revelação confiada ao vidente de Patmos para ser transmitida a todos os membros do Corpo d'Aquele "que-é", "que-era" e "que-vem" (Ap 1,4).

\section{O Dia do Senhor}

O hino "aleluiático" de Ap 19,1-7 pode ser considerado um dos vértices mais significativos de todo o Apocalipse, na medida em que considerarmos o escopo e a intenção teológica dessa preciosa obra literária. Essa perícope, no entanto, não pode ser devidamente entendida se estancada ou isolada do conjunto da obra, uma verdadeira "arquitetura em movimento", conforme definida por um grande estudioso desse livro. ${ }^{1}$ Trata-se de uma obra-prima de Deus, cujo divino artista é o próprio Espírito Santo, pessoa-dinamismo, sopro de vida, criatividade sempre atual na historia salutis e na existência de cada ser vivente. Por essa razão é fundamental que tenhamos sempre diante dos olhos o conjunto da "revelação" (apokálypsis) de Jesus Cristo destinada à salvação de todos os seus servos (Ap 1,1). As etapas que seguirão a esse anúncio serão como que desdobramentos e fases graduais que intentam, de forma dinâmica e crescente, atingir o preciso escopo desenhado pelo autor do projeto.

Antes de testemunhar o Kýrios às Igrejas da Ásia Menor, o vidente de Patmos declara solenemente que foi precisamente o "Dia do Senhor" o momento e ponto de arranque de todo o trajeto que, doravante, irá percorrer com os ouvintes e leitores do livro (Ap 1,10). Dizer "no Dia do Senhor" expressão proposta num dativo locativo, segundo a gramática grega - significa localizar não apenas cronologicamente, mas também "kairologicamente" o tônus da revelação que o vidente deseja comunicar. Em outros termos, o que aqui está em questão, sobretudo, é o significado bíblico e histórico-salvífico do evento da ressurreição de Jesus e de sua celebração.

O Dia do Senhor, de fato, pode ser tido, à luz do contexto teológico do Apocalipse, como a matriz gerativa que dá origem e sentido à fé cristã, uma vez que nele - kairós privilegiado para a celebração do memorial da salvação - o Kýrios se dá a conhecer como o Senhor dos dias, como aquele que inaugura o tempo novo, o "dia da salvação" (2Cor 6,2). "É no Dia do

${ }^{1}$ ELLUL, J., Apocalipse. Arquitetura em movimento, p. 35-63. 
Senhor, memorial da Páscoa da ressurreição, quando a comunidade cristã se reúne para celebrar a liturgia eucarística, que João recebe a Palavra de Deus. João sublinha o contexto eclesial litúrgico no qual recebeu a revelação". ${ }^{2}$

A celebração "com seus gestos, ritos e tudo aquilo que compõe o seu quadro litúrgico, é uma nota capital que dá sentido à sinfonia da mensagem do 'Livro da Revelação' - 'sinfonia' por conta da riqueza multifacética de elementos simbólicos e rituais que tecem a melodia da mística liturgia, que é essa obra joaneia". ${ }^{3}$ Com toda a probabilidade, esses elementos cultuais descritos no livro eram familiares a João e às Igrejas às quais se destina a obra. ${ }^{4}$ Segundo U. Vanni, o Dia do Senhor se caracteriza essencialmente por ser o dia do "encontro dominical" dos cristãos e se constitui na expressão da "típica assembleia do domingo, que acontecia na Ásia Menor, no âmbito da Igreja joaneia". ${ }^{5}$ O "Dia do Senhor", segundo aquilo que nos sugere o Apocalipse, é o locus e o momento privilegiados para a celebração da liturgia eucarística. Ao dizer que a celebração da Eucaristia é o "centro e cume de toda a vida da comunidade cristã", ${ }^{6}$ particularmente no âmbito do domingo, o Concílio Vaticano II outra coisa não faz senão ecoar a viva e vibrante experiência que já se encontra registrada na teologia do livro do Apocalipse.

No item em questão, o interesse da nossa abordagem, no entanto, é considerar o laço visceral que existe entre o Dia do Senhor e a celebração da Liturgia das Horas. Com efeito, a reforma litúrgica pós-conciliar fez a precisa escolha de introduzir a perícope de Ap 19,1-7 na celebração das II Vésperas dos domingos do ano litúrgico, exceto nos domingos do Tempo da Quaresma. Poder-se-ia ventilar algumas razões que justificaram essa consciente opção; aqui desejamos destacar aquelas de ordem teológico-litúrgica.

\footnotetext{
${ }^{2}$ BIANCHI, E., L’Apocalisse di Giovanni, p. 50.

3 A teologia subjacente na mensagem do Apocalipse tem um cunho profundamente cristológico-liturgico. Essa abordagem foi muito elaborada por U. Vanni (VANNI, U., L'Uomo dell'Apocalisse, p. 175-195).

4 NUSCA, R. A., Liturgia e Apocalisse, p. 464: “[...] La publicazione di K.P. Jörns, Das hymnische Evangrlium (1971) ha dimostrato che gli 'inni' costituiscono delle composizioni originali dell'autore, anche se certo contengono elementi desunti dalle tradizioni familiari al Veggente (trisagion, amen, dossologie, aclamazioni, allelujah, ecc.) e in tal modo sono testimoni indiretti della liturgia primitiva. Più che adattare degli inni pre-esistenti o formulare sequenze liturgicche in base a specifici contesti lturgici, Giovanni ha costruito delle compositioni inniche originali che riflettono il linguaggio della liturgia con cui era familiare".

${ }^{5}$ VANNI, U., Apocalisse. Libro della rivelazione, p. 37.

${ }^{6} \mathrm{CD} 30$.
} 
À luz do pensamento do Concílio Vaticano II, uma das principais razões diz respeito à dimensão bíblica e teológica do Dia do Senhor. ${ }^{7}$ Celebrar a memória da opus salutis, o memorial pascal do Kýrios, é a primordial missão da Igreja, de modo particular, no Dia do Senhor, definido como o "principal dia de festa" e "fundamento e o núcleo do Ano Litúrgico". ${ }^{8}$ Ao se referir ao domingo dessa forma tão profunda e intensa, o Concílio se apóia na teologia bíblico-patrística, tão cuidadosamente resgatada pelo Movimento Litúrgico da primeira metade do século $\mathrm{XX}$.

O domingo é considerado o "núcleo" do Ano Litúrgico porque o memorial que nele se celebra tem a potência de colocar os membros do Corpo de Cristo em contato com o "hoje" da salvação realizada pela morte e ressurreição do Senhor. Dessa forma podemos afirmar que a Igreja, a cada vez que, no Dia do Senhor, "recorda" o dom da salvação pascal, torna-se um autêntico sacramento, por meio do qual os batizados se tornam sinais e testemunhas das maravilhas de Deus operadas ao longo da revelação bíblica e plenamente cumpridas na páscoa de Jesus. Em forma de "economia da salvação" recordada e atualizada no culto, a celebração dominical se torna, ao mesmo tempo, "memorial" e "profecia". Nesse sentido podemos considerar o domingo, como o "diamemorial" por excelência, "o dia da evocação adorante e grata do primeiro dia do mundo e, ao mesmo tempo, da prefiguração vivida na esperança do 'último dia', quando Cristo vier na sua glória (At 1,11; 1Ts 4,3-17) e renovar todas as coisas (Ap 21,5)". ${ }^{9}$

Celebrando a Liturgia das Horas nas II Vésperas no Dia do Senhor, e servindo-se do hino aleluiático de Ap 19,1-7, a comunidade eclesial de todos os tempos revive em si mesma, em toda a sua magnitude, a experiência da vitória pascal do Cristo, celebrada e testemunhada pelo místico de Patmos e por seus irmãos na fé. O “Amém, Aleluia" (v.4) entoado na liturgia dominical do Apocalipse se protrai na ecclesia orans e torna-se o hino pascal dos redimidos, sempre que o Ofício Divino é celebrado. Por essa razão, a reforma litúrgica pós-conciliar relê a celebração memorial da Liturgia das Horas como o ecoar infinito, no tempo e no espaço, do "hino" que o eterno Filho do Pai eternamente cantava nas "habitações celestes". Em virtude do mistério

\footnotetext{
${ }^{7}$ Acerca da dimensão teológica e mistagógica do Dia do Senhor à luz do pensamento conciliar sugerimos o seguinte estudo: GIRAUDO, C., La mistagogia della domenica come struttura permanente della pastorale, p. 183-203.

${ }^{8} \mathrm{SC} 106$.

${ }^{9}$ DD 1.
} 
da encarnação, esse hino se prolonga no Corpo de Cristo até a consumação dos tempos: "O Sumo Sacerdote do novo e eterno Testamento, Cristo Jesus, assumindo a natureza humana, trouxe para esse exílio terrestre aquele hino que é cantado por todo o sempre nas habitações celestes. Ele, associa a si toda a comunidade dos homens, e une-a consigo na celebração deste divino cântico de louvor". ${ }^{10}$

A cada vez que celebra as primeiras Vésperas no Dia do Senhor, a Igreja toma consciência de estar transpondo um limiar e é convidada a preparar-se para abraçar o Cristo que vem ao seu encontro. Com encanto e estupor ela se abre para receber com gratidão o "sacramento" do "Dia do Senhor". Ao proceder dessa forma, ela também vai se dando conta de que, de domingo a domingo, avança em sua peregrinação rumo à meta que já lhe foi insinuada: "Na liturgia terrena, antegozando, participamos da liturgia celeste, que se celebra na cidade santa de Jerusalém, para a qual, peregrinos, nos encaminhamos". ${ }^{11}$ Concluindo esse dia pascal com a celebração das II Vésperas - quando ganha particular relevo a perícope bíblica que norteia o nosso estudo - os cristãos se preparam para recomeçar o ciclo de mais uma semana, convencidos de que "o homem perfeito, que está sempre ocupado em palavras, ações e pensamentos com o Verbo de Deus, vive permanentemente nos dias do Senhor, e todos os dias lhe são domingos". ${ }^{12}$ Os batizados, dessa forma, por puro dom, se percebem chamados e capacitados a viver "em" / "da" sua condição transfigurada de membros do Corpo de Cristo no mundo.

Reproduzindo em si mesmos o hino cantado pelos redimidos no sangue do Cordeiro - sempre cantando-o de novo e de forma nova no canto das Vésperas - os cristãos são chamados a testemunhar aos seus irmãos de peregrinação que, através da celebração pascal do Ofício Divino, "o nosso ser participa do louvor ao Pai por seu Filho no seu Espírito Santo. Nosso ser 'pessoal', corpo, alma, espírito e coração, torna-se oração em cada uma de suas fibras, mas também o nosso ser 'em relação divina', pois é a comunidade que ora, e, finalmente, nosso ser 'no tempo', já que esse tempo atual e mortal é transformado em oferenda no orvalho do Espírito". ${ }^{13}$

\footnotetext{
${ }^{10} \mathrm{SC} 83$.

${ }^{11} \mathrm{SC} 8$.

${ }^{12}$ ORÍGENES, Contra Celso, 8,22. Apud CORBON, J., A fonte da liturgia, p. 139.

${ }^{13}$ CORBON, J., A fonte da liturgia, p. 140.
} 


\section{A experiência com o Ressuscitado na assembleia dominical}

Conforme anteriormente registrado, o "Dia do Senhor" é o kairós por excelência para se celebrar o memorial de páscoa do Senhor. A comunidade cristã reunida é a assembleia eclesial qualificada como hermeneuta da revelação (apokálipsis) que the é entregue e confiada. ${ }^{14}$ Que a recente pesquisa bíblica sobre o Livro do Apocalipse esteja sempre mais descobrindo a importância inconteste do tema da assembleia litúrgica nessa obra joaneia é algo já comprovado. Um de seus mais insignes representantes é U. Vanni. Em uma sua pesquisa dedicada à hermenêutica, exegese e teologia do Apocalipse, ele assim intitula um dos capítulos: "A assembleia eclesial: sujeito intérprete do Apocalipse". Nesse mesmo capítulo, após uma premissa, ele elenca os elementos essenciais que caracterizam o dinamismo e a beleza da assembleia litúrgica descrita na obra do vidente de Patmos: "Feliz aquele que lê e aqueles que escutam", "Do leitor a João, dos ouvintes ao grupo eclesial", "Um apelo à conversão que encontra acolhimento", "A leitura cristã da história", "Aquele que escuta diga: Vem! $(22,17)$. A postura conclusiva da hermenêutica, exegese e teologia do Apocalipse do grupo eclesial de escuta". ${ }^{15}$

No nosso hino "aleluiático" $(19,1-7)$ notamos a importância bíblicolitúrgica do verbo "ouvir" ('akoúo). Por duas vezes o vidente assegura que ouviu (v.1.6). Sua postura é paradigmática e representativa para a assembleia litúrgica que se coloca como transfundo da trama do Apocalipse; é também a postura que se exige de todo aquele que, na atração do Espírito Santo, passa a formar o tecido de uma assembleia litúrgica, lugar por excelência da escuta da Palavra de Deus e, em consequência, de sua resposta. ${ }^{16}$ Afinal de contas, é mormente na reunião cultual que se realiza em plenitude aquela exigência feita pelo Senhor à comunidade de fé do antigo Israel: "Ouve, ó Israel: Iahweh nosso Deus é o único Iahweh. Portanto, ó Israel, amarás a Iahweh teu Deus com todo o teu coração, com toda a tua alma e com toda a tua força" (Dt 6,4-5).

Segundo a nossa perícope, o canto "aleluiático" somente poderá ser entoado por uma assembleia que se adestrou em ouvir o testemunho das

\footnotetext{
${ }^{14}$ Conferir o interessante estudo sobre a assembleia litúrgica como "sujeito intérprete" do Apocalipse: VANNI, U., Divenire nello Spirito, p. 71.

${ }^{15}$ VANNI, U., L'Apocalisse, p. 74-86.

${ }^{16}$ CULLMANN, O., La preghiera nel Nuovo Testamento, p. 190. 'L' 'udire' ha un'importanza straordinaria nell'Apocalisse. Il vegente non 'vede' soltanto, ma soprattutto ode. Ode la 'voce' di coloro che nei testi citati intonano i canti di lode".
} 
magnalia Dei, daquelas obras maravilhosas operadas pelo Senhor em prol de seu povo. Um dos exemplos mais vibrantes disso, no nosso texto, é o definitivo julgamento da "grande prostituta", clara amostra de que a Palavra do Senhor é eficaz e os seus julgamentos são "verdadeiros e justos" (Ap 19,2), dignos de ser acolhidos e obedecidos. ${ }^{17}$

É importante aqui assinalar que a assembleia do Apocalipse é herdeira direta da singular vocação de Israel, povo forjado pela escuta e para a escuta. Dentre os vários testemunhos do povo da primeira aliança, poderíamos mencionar a solene assembleia de escuta e renovação do pacto da aliança, sob a presidência de Esdras e Neemias (Ne 8). Certamente, envolvida por um comovente clima de escuta geradora de uma incomparável alegria, aquela reunião cultual poderia ser relida como uma autêntica profecia da assembleia descrita no Apocalipse.

Ao acolher na fé e na obediência a Palavra daquele que é o único capaz de receber e deslacrar o livro da vida - o "Cordeiro de pé, como que imolado" $(5,6)$ - a assembleia litúrgica descrita em nossa perícope é cinzelada e transformada num corpo orante e capaz de ouvir, condição sine qua non para se tornar hermeneuta e exegeta do plano divino da salvação e dos sinais dos tempos. "Depois disso ouvi [...]. Ouvi depois disso [...] (19,1.6): é a dinâmica processual da escuta na assembleia cultual. Assim como é contínua a revelação, sempre mais profunda deve ser a escuta. E tudo isso provoca a necessária atitude de resposta. Então o diálogo se instaura. A assembleia cultual do Apocalipse é formada de leitor e ouvintes, tendo como protagonista Aquele que "tem a espada afiada de dois gumes" $(2,12) .{ }^{18}$ Trata-se da penetrante Palavra de Deus (Hb 4,12). Convocada pela Palavra da vida, a assembleia é "pró-vocada" por essa mesma Palavra, ou seja, é instigada a respondê-la a fim de prosseguir o seu caminho de fé no culto e na vida. ${ }^{19}$

\footnotetext{
17 “Longe de ser uma violência que se sofre e uma submissão passiva, a obediência, livre adesão ao desígnio de Deus, ainda encerrado no mistério, mas proposto à fé pela Palavra, possibilita ao homem fazer de sua vida um serviço a Deus e entrar no seu gozo", AUGRAIN, C.; GUILLET, J., Obediência, p. 666.

${ }^{18}$ VANNI, U., Apocalipse, 1984, p. 90-92.

${ }^{19}$ NUSCA, A. R., endossando o parecer de Vanni, ressalta que o diálogo litúrgico-cultual, em assembleia, no Dia do Senhor e a dinâmica "leitor"-“ouvinte" estão presentes em toda a mensagem do Apocalipse, do primeiro ao último capítulo, NUSCA, A. R., Liturgia e Apocalisse, p. 462. E ainda: "Il veggente intende che il suo lavoro venga letto a modo di lettera alle chiese dell'Asia Minore. La menzione specifica del "giorno del Signore" in 1,10 e le ulteriori allusioni al contesto liturgico in 22,17-20, tutto questo suggerisce che il constesto in cui l'Apocalisse doveva essere letta non è semplicemente pubblico, ma più probabilmente liturgico/cultuale” (p. 461).
} 
Essa mesma tônica assembleal do Apocalipse pode ser encontrada na Igreja que se reúne para celebrar a Liturgia das Horas no Dia do Senhor. Trata-se da ecclesia orans, comunidade de fé atraída pelo Espírito de Deus para ouvir e testemunhar as obras maravilhosas do Senhor cantadas nos poemas sálmicos. Síntese de todas essas maravilhas é a ressurreição de Cristo, profeticamente anunciada pelo autor sagrado em seu hino pascal: "Este é o dia que o Senhor fez para nós. Alegremo-nos e nele exultemos" (S1 117(118),24). ${ }^{20}$ A comunidade orante no Dia do Senhor sente-se ressuscitada com Cristo e participante de sua ressurreição. Animada pelo Espírito que ressuscitou Jesus dentre os mortos (Rm 8,11), ela une-se ao seu Senhor e a todos os homens na participação daquela oração que provém do Espírito e nos põe em contato com a "Hora" pascal de Jesus. É esta "Hora" que faz com que a celebração dominical da Opus Dei se converta numa experiência de ação de graças, num "sacrifício de louvor", numa "eucharistia": o louvor daqueles que, ainda estando neste mundo, já se percebem participantes da liturgia celeste. "O cristianismo aplicou de modo particular a expressão 'sacrifício de louvor' à celebração eucarística, o verdadeiro e perfeito sacrifício da nova lei, porque expressão máxima do homem a Deus, manifestação iminente do interno sentimento do homem. Mas com essa expressão 'sacrifício de louvor' se quer indicar também o Ofício Divino, a oração pública da Igreja”. ${ }^{21}$

Momento privilegiado e único, o "sacrifício de louvor" vespertino oferecido a Deus, por meio do Ofício Divino, na celebração memorial do Dia do Senhor, é um aspecto que caracteriza a Igreja como povo de Deus, comunidade daqueles que se reconhecem participantes do Espírito que ressuscitou Jesus e nele habita. Esse aspecto orante da comunidade dos batizados foi um dos mais preciosos tesouros que nos legou a reforma litúrgica pós-conciliar: "A oração pública e comum do povo de Deus é com razão contada entre as principais funções da Igreja. Já nos inícios os batizados "perseveravam no ensinamento dos apóstolos, na comunhão, na fração do pão e nas orações" (At 2,42). Várias vezes os Atos dos Apóstolos atestam que a "comunidade cristã orava em comum". ${ }^{22}$ De fato, insistir na importância da dimensão eclesial da

\footnotetext{
${ }^{20}$ Servindo-se da interpretação tipológica e inspirando-se na leitura neotestamentária, a Tradição dos Padres da Igreja reconhecem nesta declaração do Salmo o dia da ressurreição de Cristo. Citemos apenas alguns deles: Orígenes, Atanásio, João Crisóstomo e Jerônimo, NESMY, J. C., I Padri commentano il Salterio della Tradizione, p. 624

${ }^{21}$ CUVA, A., La Liturgia delle ore, p. 12.

${ }^{22}$ IGLH 1.
} 
Liturgia das Horas foi uma das maiores preocupações dos padres conciliares. Preocupação justificada, uma vez que o que está em jogo é a realidade da natureza da Igreja e de seus atos litúrgicos: a Igreja é o Corpo orante de Cristo. Nesse sentido afirma o Concílio: "Ele [Cristo] continua aquela sua sacerdotal através de sua Igreja, que, não somente pela celebração da Eucaristia, mas também por outros modos, particularmente rezando o Ofício divino, louva sem cessar o Senhor e intercede pela salvação de todo o mundo". ${ }^{23}$

A importância assembleal da Liturgia das Horas é de tal forma capital para o ser, a missão e o testemunho da Igreja, que o Vaticano II chega a sugerir aos pastores do Povo de Deus que essa oração seja celebrada em comum: "Cuidem os pastores de almas que as Horas principais, especialmente as Vésperas, nos domingos e dias de festas mais solenes, sejam celebradas em comum na Igreja. Recomenda-se que também os leigos recitem o Ofício divino, ou com os sacerdotes, ou reunidos entre si, e até cada um em particular". ${ }^{24}$

Segundo a perspectiva da nossa reflexão, é fulcral salientar que, por meio da celebração da Liturgia das Horas, no Dia do Senhor - foco da nossa proposta -, se evidencia a dimensão pascal e reveladora do eterno projeto salvífico de Deus e da obra da redenção pascal realizada por Cristo. Ao Espírito Santo cabe a tarefa de tornar o Cristo presente em meio aos seus sempre que se reúnem em assembleia de culto. O memorial litúrgico, dessa forma, se transforma em contexto vital e privilegiado para se compreender bem esta promessa do Senhor: "E eis que estarei convosco todos os dias, até a consumação dos séculos" (Mt 28,20). No âmbito do mistério da liturgia vê-se o profundo laço de parentesco que une a celebração da Eucaristia e a da Liturgia das Horas. Tanto naquela como nesta encontra-se o Cristo presente em meio aos seus, louvando o Pai, na força de seu Espírito. Retomando um pensamento da Instrução Geral à Liturgia das Horas, esse laço se explicita: "Nela [na oração da Liturgia das Horas] Cristo está presente, na reunião da assembléia, na proclamação da Palavra de Deus e na Igreja que suplica e salmodia". ${ }^{25}$ Inspirando-se agora na teologia da Constituição Litúrgica Sacrosanctum Concilium, a Instrução Geral reconhece o caráter sacramental da presença do Ressuscitado em meio à assembleia que celebra o Ofício Divino: "Cristo está sempre presente em sua Igreja, sobretudo nas ações litúrgicas". ${ }^{26}$

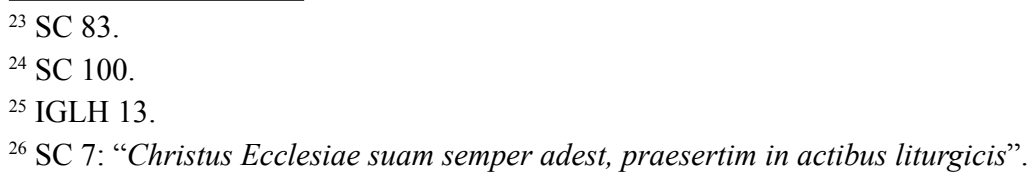




\section{A Liturgia das Horas: uma celebração doxológico-nupcial}

O hino aleluiático de Ap 19,1-7 é uma peça de estilo essencialmente doxológica e nupcial: ${ }^{27}$ "Dai louvores ao nosso Deus [...]. Alegremo-nos e exultemos, demos glória a Deus, porque chegou o tempo das núpcias do Cordeiro, e sua esposa já está pronta" (v.5.7). Por essa razão ensejamos salientar esse caráter do hino, que julgamos fundamental no conjunto da perícope. O estilo doxológico e nupcial do nosso hino tem sua inspiração na tradição sálmica e profética, que a fé cristã herdou da espiritualidade judaica.

A começar pelo primeiro aspecto, ${ }^{28}$ podemos constatar em muitos Salmos utilizados na oração de Israel o termo "hallēlouia", "louvai a Iahweh" - aclamação litúrgica usada com frequência no culto israelita. Trata-se de uma “exclamação litúrgica [...] sobretudo em todos os salmos aleluiáticos (111-112 no início, 104-105 no fim, 106.113.135.146-150 no início e no fim. Aleluia é um acréscimo litúrgico [...] entoado, originariamente, pelo chantre (sacerdote ou levita), e repetido pelo povo". ${ }^{29}$ No Novo Testamento, "hallēlouia" encontra-se apenas na perícope que estamos considerando, precisamente nos versículos 1.3.4.6.

Em Ap 19,1, João, "servo de Deus" e testemunha da profecia recebida na assembleia cultual, declara que ouve "como que um forte rumor de numerosa multidão no céu que exclama: Aleluia! A salvação, a glória e o poder do nosso Deus". Em seguida, lhe é mostrado o motivo desse canto, que inesperadamente prorrompe da "numerosa multidão" que participa daquela liturgia: Babilônia, a grande meretriz, que corrompeu a terra com a sua prostituição, foi julgada. Estamos diante de "uma das doxologias mais belas e interessantes [...]. (Ela) tem uma dupla direção: de um lado reassume a destruição de Babilônia, de outro lado prepara a celebração da Jerusalém nova. Um ponto de passagem da

\footnotetext{
${ }^{27}$ A dimensão nupcial da Igreja aqui proposta se limita ao nosso hino aleluiático. É importante, porém, ressaltar que ela está também fortemente presente nos capítulos 21 e 22 do nosso livro. A respeito consultar o sugestivo estudo de Luca Pedroli: PEDROLI, L., Dal fidanzamento alla nuzzialità escatológica, p. 271-340.

${ }^{28}$ Desejando enfatizar a dimensão laudatória da Liturgia da Horas, o Papa Paulo VI assim intitulou a sua Constituição que oficializava a oração da Liturgia das Horas para a Igreja, de acordo com a teologia do Concílio Vaticano II: "Laudis Canticum" (promulgada no dia 1 de novembro de 1970). Assim inicia o Documento: "O cântico de louvor, que ressoa eternamente nas moradas celestes, e que Jesus Cristo, Sumo Sacerdote, introduziu nesta terra de exílio, foi sempre repetido pela Igreja, durante tantos séculos, constante e fielmente, na maravilhosa variedade de suas formas".
}

${ }^{29}$ VAN DER BORN, A., Aleluia, p. 33. 
cidade como simbolismo feminino 'negativo' à cidade 'iluminada' ao máximo grau, símbolo 'positivo' da cidade que se torna esposa". ${ }^{30}$

Após o canto festivo do segundo Aleluia, o "vidente-ouvinte" da profecia nos coloca em contato com um dado ritual-sacramental bastante significativo: a prostração dos quatro anciãos e dos quatro animais - continuação do hino aleluiático, grito silencioso do louvor doxológico, plasticamente expresso na expressão corporal, evocadora de total entrega e abandono Àquele que está sentado no trono (v.4). ${ }^{31}$ Quase que exprimindo uma concomitância, a cena se dilata e passamos a ter: "[...] se prostraram [...]" e "[...] dizendo: Amém, Aleluia!". Agora, ao Aleluia das duas ocorrências anteriores, se acrescenta um Amém. Após o louvor radiante e cheio de júbilo, agora nos deparamos também com o "assim é", "assim seja" - acolhimento irrestrito e sem condições do projeto divino, das promessas do Senhor aos seus eleitos e de todos os seus atos realizados ao longo da economia salvação. Com efeito, a assembleia eclesial é aqui desafiada a confiar total e plenamente no Deus da vida e no Senhor da história, apesar de todas as evidências contrárias que emergem da história de cada um de seus membros e da realidade do mundo como um todo. E essa profissão de fé deve se expressar numa permanente atitude de louvor: "Dai louvores ao nosso Deus, vós todos seus servos, e vós que temeis o Senhor, pequenos e grandes" (v.5).

O místico de Patmos ouve, então, "como que o rumor de uma grande multidão", onde parece se verificar uma sinfonia cantada em dois coros, porque "a assembleia litúrgica terrestre acolhe o convite e se une àquelas celeste em um só louvor": 32 "Aleluia! Porque o Senhor passou a reinar! Alegremo-nos e exultemos, demos glória a Deus, por que chegou o tempo das núpcias do Cordeiro, e sua esposa já está pronta" (v.6b-7).

“Aleluia!". Pela quarta vez, no âmbito da nossa perícope, emerge o hino "aleluiático". Nesse momento a assembleia litúrgica terrestre se dá conta de que o Senhor se faz presente naquela celebração de ação de graças, como aquele que reina, e isso se transforma em motivação para

\footnotetext{
${ }^{30}$ VANNI, U., Apocalisse. Libro della rivelazione, p. 169.

${ }^{31}$ ORSATTI, M., L'arte di pregare alla scuola del Nuovo Testamento, p. 193: "La tonalità liturgica viene evidenziata opportunamente con la riapparizione dei ventiquattro anziani e dei quattro esseri viventi. Essi hanno anche la funzione di portare le aspirazioni e le e azioni dell'assemblea liturgica a Dio, interpretando il suo atteggiamento interiore: esso $\grave{\mathrm{E}}$ costituito da un "amen" (“così è"): è l'accoglienza senza condizioni di tutto l'insieme degli interventi di Dio".
}

${ }^{32}$ VANNI, U., Apocalisse, p. 120. 
o seu louvor: "Alegremo-nos e exultemos, demos glória a Deus". A comunidade celeste, por sua vez, se mostra em profunda comunhão com os que ainda atravessam a "grande tribulação" (Ap 7,14). ${ }^{33}$ Essa profunda comunhão - liturgia terrena e celeste - se expressa nos verbos usados na primeira pessoa do plural ("alegremo-nos", "exultemos", "demos glória") e ganha uma tonalidade de "confissão de fé": "O Senhor, o Deus todopoderoso passou a reinar".

Quanto ao segundo aspecto - a dimensão nupcial - torna-se indispensável considerar o trecho final do nosso hino: "Porque chegou o tempo das núpcias do Cordeiro, a sua esposa está pronta" (v.7b). Qual seria o significado da expressão "sua esposa está pronta" no contexto da teologia proposta pelo Apocalipse? Para se compreender corretamente essa expressão, devemos nos dar conta de que, nesta altura do hino, já respiramos o momento escatológico, ${ }^{34}$ o clímax da historia salutis arquitetada por Deus desde toda a eternidade. Já se pode entrever a Jerusalém celeste e a esposa do Cordeiro, preparada para as núpcias eternas. "Interpretando o sentido do simbolismo, o autor quer indicar os santos que estão na terra e, mais precisamente, a Igreja que está em caminho, ainda noiva, mas na soleira da nupcialidade, totalmente empenhada no amor para com Cristo, praticando ações de justiça". ${ }^{35}$ João, o poeta que dá testemunho do eterno amor de Deus, concretamente expresso no plano divino da salvação, demonstra captar em profundidade o sentido da teologia nupcial, tão cara ao profetismo da primeira aliança. Em passagens como Is 54,6ss; Os 2,16ss; Ez 16,6ss, Iahweh é comparado a um esposo que anela por uma esposa que corresponda à intensidade do seu amor. Por isso faz uma aliança com Israel, mantendo-se fiel e, pedagogicamente, formando e educando seu partner para corresponder ao seu programa de nupcialidade. Porém, somente com a "nova e eterna aliança", inaugurada pela páscoa do Cordeiro, esse desejo do Eterno se tornou possível. É isso que, com admiração e entusiasmo,

${ }^{33}$ NUSCA, R. A., Liturgia e Apocalisse, p. 470: "Grazie alle configurazioni cultuale/liturgiche del libro, tempi e luoghi diversi si fondono, permettendo al Veggente di convocar un un'unica communitas Dio e l'Agnello, i membri della corte celeste, i martiri futuri, come pure le comunità oranti delle 'sette chiese' al cui centro sta un Gesù raggiante [...]. E i destinatari sono invitat a unire le oro voci alle lodi celesti, come pure partecipare attivamente nel combattimento spirituale descritto nel libro".

${ }^{34}$ Acerca da dimensão escatológica do livro do Apocalipse, conferir: VANNI, U., Dal Quarto Vangelo all'Apocalisse, p. 87-113.

${ }^{35}$ VANNI, U., Apocalisse. Libro della rivelazione, p. 172. 
cantam os membros da liturgia celeste do Apocalipse: "Chegou o tempo das núpcias do Cordeiro, a sua esposa está pronta". ${ }^{36}$

A vocação nupcial da Igreja quer ser o ponto de partida para se estabelecer um nexo entre a Liturgia das Horas e o nosso hino "aleluiático". Somos levados a crer que é da teologia da nupcialidade, profundamente bíblica, que o Concílio Vaticano II formula o seguinte pensamento acerca da opus Dei: "Por antiga tradição cristã o Ofício divino está constituído de tal modo que todo o curso do dia e da noite seja consagrado pelo louvor de Deus [...]. Ele é "a voz da própria Esposa, que fala com o Esposo, ou melhor, é a oração de Cristo, com seu próprio Corpo, ao Pai". E continua no parágrafo seguinte: "Por conseguinte, todos os que se entregam a isso, não somente satisfazem o Ofício da Igreja, como também participam da honra suprema da Esposa de Cristo, porquanto cantando os louvores a Deus estão diante de seu trono em nome da Mãe Igreja". ${ }^{37}$ As dimensões de esponsalidade e nupcialidade da Igreja, profundamente relacionadas entre si, ganharam um particular relevo na abordagem eclesiológica proposta pelo Concílio Vaticano II. ${ }^{38}$ A partir desse estímulo do Magistério, não se pode aqui deixar de mencionar o interesse que a eclesiologia pós-conciliar tem demonstrado em investigar o aspecto da vocação nupcial da Igreja, sempre à luz da teologia bíblica e patrística. ${ }^{39}$

\footnotetext{
36 "[...] concederam-lhe vestir-se com linho puro, resplandecente", continua o texto joanino no versículo 8 , que não faz parte da perícope litúrgica do texto selecionado para a oração da Liturgia das Horas. Nós o destacamos, porém, nesta nota de rodapé por considerarmos a sua importância no conjunto do nosso comentário. 'Essa veste exprime a personalidade da 'esposa': aquela positividade sem sombras que se realizará na fase escatológica, à qual a assembleia litúrgica está imaginada, reinventando em forma de canto" - PRINGENT, P., L'Apocalissi di S. Giovanni, p. 562. Revestidos de Cristo desde o batismo (G1 3,27), os cristãos tornam-se membros qualificados da assembleia litúrgica do Dia do Senhor. Celebrando a vitória do Kýrios sobre a morte e o pecado e testemunhando no mundo o que celebram, os batizados já começam a se vestirem "com linho puro, resplandecente".

${ }^{37} \mathrm{SC} 84$ e 85.

${ }^{38}$ Referimo-nos aqui à tratativa da índole escatológica da Igreja peregrina e a sua união nupcial com a Igreja celeste, objeto do VII capítulo da Lumen Gentium.

39 A esse respeito sugerimos as seguintes obras: MAZZANTI, G., Mistero pasquale; MAZZANTI, G., Teologia sponsale e sacramento delle nozze; MAZZANTI, G., Da Cana la luce; MAZZANTI, G., Persone nuziali; MELLO, A (Org.)., Rashi di Troyes; RAVASI, G., Cantici dei Cantici; LORENZIN, T., Cantico dei Cantici; BARSOTTI, D., Meditazione sul Cantico dei Cantici; BONATO, V. (Org.)., Gregorio di Nissa; CREMASHI, L., Il più bello canto d'amore; LIMONE, V.; MORESCHINI C. (Orgs.)., Origene - Gregorio di Nissa; DE CHERGÈ, C., Meditazioni sul Cantico dei Cantici; STANDAERT, B., Cantico dei Cantici.
} 


\section{Conclusão}

Anelando por celebrar o Ofício Divino na conclusão do Dia do Senhor, a Igreja abraça aquilo que a caracteriza como "mistério": sacramento de Cristo, Esposa do Cordeiro imolado e ressuscitado. Atraída e animada pelo Espírito que nela habita, a Igreja, como a amada do Cântico dos Cânticos, se declara seduzida pelo seu Esposo: "Arrasta-me contido, corramos! Leva-me, ó rei, aos teus aposentos e exultemos! Alegremo-nos em ti! Mais que ao vinho, celebremos teus amores!" (Ct 1,4). Tendo sido seduzida e feito a sua confissão de amor, ela mesma se dá conta do significado do seu "ofício" - é realmente “divino": "O 'Ofício' da Esposa é então 'divino'; sua única ocupação consiste em amar [...]. O Ofício é a nossa penetração encarnada na própria oração de Jesus [..]. Sem dúvida alguma, o Ofício é divino, a divina ocupação por excelência, a do Reino do amor". 40

A oração vespertina - e aqui enfatizamos aquela do Domingo - deve ser considerada também em seu valor simbólico e teológico. O anoitecer, na experiência bíblica, é ocasião propícia para ação de graças. Na perspectiva cristã, é a ocasião em que a comunidade orante celebra o memorial da obra da redenção realizada pela páscoa de Cristo e atualizada na vida da Igreja e do mundo. ${ }^{41}$ Ao mesmo tempo, é no memorial vespertino que a esperança cristã se nutre da luz que não conhece ocaso, aquela luz que ilumina e alimenta a liturgia celeste, conforme declara o vidente de Patmos àqueles que ainda peregrinam na penumbra deste mundo: "A cidade não precisa do sol ou da lua para a iluminarem, pois a glória de Deus a ilumina, a sua lâmpada é o Cordeiro" (Ap 21,23).

“A Esposa de Cristo, animada pelo Pneûma da ressurreição, canta sem cessar a ação de graças, em resposta ao agápe, amor benevolente e totalmente gratuito do Deus e Pai de Nosso Senhor Jesus Cristo". ${ }^{42}$ A obra do Espírito,

\footnotetext{
${ }^{40}$ CORBON, J., A fonte da liturgia, p. 140-141.

${ }^{41}$ IGLH 39. Ainda: "A Liturgia das Horas ressalta e recorda, em chave de adoração e de louvor, a conexão comemorativa que existe entre as horas e as obras do Salvador, e, inserindo os seres infra-racionais na esfera da salvação cristã, contribui para a sua libertação e para a sua participação na glória dos filhos de Deus ( $\mathrm{Rm} \mathrm{8,19-21).} \mathrm{A} \mathrm{Liturgia} \mathrm{das} \mathrm{Horas} \mathrm{realça}$ grandemente a dignidade do homem como sacerdote da criação, isto é, como mediador de louvor entre as coisas criadas e Deus. A Liturgia das Horas assim, através do orante, se transforma em gigantesco cântico das criaturas que bendizem o seu criador", RAFFA, V., Liturgia das Horas, p. 668.

${ }^{42}$ DE REYNAL, D., Teologia da Liturgia das Horas, p. 30-31.
} 
com efeito, consiste em suscitar no coração da Igreja o louvor incessante ao Deus fiel e amoroso. Isso faz com que a dimensão nupcial da celebração da Liturgia das Horas se una àquela doxológica. De forma antecipada, a ecclesia orans entra em contato com o louvor eterno, que será inaugurado definitivamente por ocasião da vinda do Senhor, da páscoa escatológica. De fato, segundo a fé da Igreja, "na liturgia terrena, antegozando, participamos da liturgia celeste, que se celebra na cidade santa de Jerusalém, para a qual, como peregrinos, nos encaminhamos". ${ }^{43}$ É assim que a assembléia litúrgica, mormente na celebração vespertina do Dia do Senhor, reaviva a sua esperança da visão escatológica: "Pelo louvor tributado a Deus nas Horas, a Igreja se associa ao canto daquele divino hino de louvor que é cantado por todo o sempre nas habitações celestes; ao mesmo tempo que antegoza daquele louvor celestial descrito por João no Apocalipse e que, sem cessar, ressoa diante do trono de Deus e do Cordeiro". ${ }^{44}$

\section{Referências bibliográficas}

AUGRAIN, C.; GUILlET, J. Obediência. In: LEÓN-DUFOUR, X. (Org.). Vocabulário de Teologia Bíblica. Petrópolis: Vozes, 1977, p. 666-667.

BARSOTTI, D. Meditazione sul Cantico dei Cantici. Torino: San Paolo, 2011.

BIANCHI, E. L'Apocalisse di Giovanni. Commento esegetico-spirituale. Magnano: Qiqajon, 1988.

BONATO, V. (Org.). Gregorio di Nissa. Omelie sul Cantico dei Cantici. Bologna: EDB, 2015.

CONCÍLIO VATICANO II. Constituição Dogmática Lumen Gentium. São Paulo: Paulinas, 1977.

CONCÍLIO VATICANO II. Constituição Dogmática Sacrosanctum Concilium. Rio de Janeiro: Lumen Christi, 1985.

CONCÍlIO VATICANO II. Decreto Christius Dominus. In: CONCÍLIO VATICANO II. Compêndio do Vaticano II. Constituições, Decretos, Declarações. Vozes: Petrópolis, 1982.

\footnotetext{
${ }^{43} \mathrm{SC} 8$.

${ }^{44}$ IGLH 16.
} 
CORBON, J. A fonte da liturgia. Lisboa: Paulinas, 1999.

CREMASHI, L. Il più bello canto d'amore. Magnano: Qiqajon, 2013.

CULLMANN, O. La preghiera nel Nuovo Testamento. Torino: Claudiana, 1995.

CUVA, A. La Liturgia delle Ore. Note theologiche e spiriituali. Roma: Edizioni Liturgicae, 1975.

DE CHERGÉ, C. Meditazioni sul Cantico dei Cantici. Padova: Messaggero Padova, 2016.

DE REYNAL, D. Teologia da Liturgia das Horas. São Paulo: Paulinas, 1981. ELLUL, J. Apocalipse. Arquitetura em movimento. São Paulo: Paulinas, 1980.

GIRAUDO, C. La mistagogia della domenica come struttura permanente della pastorale. In: BARBA, M. (Org.). O giorno primo ed ultimo. Vivere la domenica tra festa e rito. Atti della XXII settimana di studio dell'Associazione Professori di Liturgia. Roma: Edizioni Liturgiche, 2005, p. 183-203.

JOÃO PAULO II, PP. Carta Apostólica Dies Domini. São Paulo: Paulinas, 2009.

LIMONE, V.; MORESCHINI C. (Orgs.). Origine - Gregorio di Nissa. Sul Cantico dei Cantici. Bompiani: Milano, 2016.

LORENZIN, T. Cantico dei Cantici. Padova: Messaggero Padova, 2001.

MAZZANTI, G. Da Cana la luce. Teologia e spiritualità del mistero nuziale. Bologna: EDB, 2005.

MAZZANTI, G. Mistero pasquale. Mistero nuziale. Meditazione teologica. Bologna: EDB, 2002.

MAZZANTI, G. Persone nuziali. Communio nuptialis. Saggio teologico di antropologia. Bologna: EDB, 2005.

MAZZANTI, G. Teologia sponsale e sacramento delle nozze. Simbolo e simbolismo nuziale. Bologna: EDB, 2004.

MELlO, A (Org.). Rashi di Troyes. Commento al Cantico dei Cantici. Magnano: Qiqajon, 1997.

NESMY, J. C. I Padri commentano il Salterio della Tradizione. Torino: Gribaudi, 1983. 
NUSCA, R. A. Liturgia e Apocalisse. Alcuni aspetti della questione. In: BOSETI, E.; CALACRAI, A. (Orgs.). Apokalipsis. Percorsi nell'Apocalisse di Giovanni in onore di Ugo Vanni. Assisi: Cittadela Editrice, 2005, p. 459478.

ORSATTI, M. L'arte di pregare alla scuola del Nuovo Testamento. Milano: Àncora, 2005.

PAULO VI, PP. Constituição Apostólica Laudis Canticum. São Paulo: Paulinas, 1971.

PEDROLI, L. Dal fidanzamento alla nuzzialità escatologica. La dimensione antropologica del rapporto tra Cristo e la Chiesa nell'Apocalisse. Assisi: Cittadella Editrice, 2015.

PRINGENT, P. L'Apocalissi di S. Giovanni. Roma: Borla, 1985.

RAFFA, V. Liturgia das Horas. In: SARTORE, D.; TRIACCA, A. M. (Orgs.). Dicionário de Liturgia. Paulinas-Paulistas: São Paulo, 1992, p. 651-670.

RAVASI, G. Cantici dei Cantici. Bologna: EDB, 1992.

SAGRADA CONGREGAÇÃO PARA O CULTO DIVINO. Texto da Instrução Geral à Liturgia das Horas. Rio de Janeiro: Lumen Christi, 1982. STANDAERT, B. Cantico dei Cantici. Il desiderio desiderato. Magnano: Qiqajon, 2017.

VAN DER BORN, A. Aleluia. In: VAN DER BORN, A. (Coord.). Dicionário Enciclopédico da Bíblia. Petrópolis: Vozes, 1977, p. 33.

VANNI, U. Apocalipse. São Paulo: Paulinas, 1984.

VANNI, U. Apocalisse. Queriniana: Brescia, 1998.

VANNI, U. Divenire nello Spirito. L'Apocalisse guida di spiritualità. Roma: Edizioni ADP, 2000.

VANNI, U. L'Apocalisse. Ermeneutica, esegesi, teologia. Bologna, EDB, 2005.

VANNI, U. L'Uomo dell'Apocalisse. Roma: Edizioni ADP, 2008.

VANNI, U. Apocalisse. Libro della rivelazione. Esegesi biblico-teologica e implicazione pastorali. Bologna: EDB, 2009.

VANNI, U. Dal Quarto Vangelo all'Apocalisse. Una comunità cresce nella fede. Assisi: Cittadella Editrice, 2011. 
Doutor em Teologia pela Pontifícia Universidade Católica do Rio de Janeiro Docente no Departamento de Teologia da Pontifícia

Universidade Católica do Rio de Janeiro

Rio de Janeiro / RJ - Brasil

E-mail: 1.fernando2250@gmail.com

Recebido em: 27/06/18

Aprovado em: 07/08/18 